\title{
Otto Neurath: Mapping the City as a Social Fact?
}

\author{
Sophie Hochhäusl, Ithaca, NY
}

\section{Introduction}

Architects are trained to distinguish between two kinds of maps: representational ones and those that serve as heuristic devices. While representational maps are usually drawn to make observations more accessible to a larger audience, the map as an architectural tool, serves as a device for design thinking. By means of drawing space it makes relationships visible that could not have been conceived without drawing. When deploying such maps, architects pay close attention to the particularities of space, because insight can only be gained when non-spatial observations are put in relationship to a certain terrain. Its synergy generates new content, meaning, knowledge and possible design solutions.

Austrian philosopher and economist Otto Neurath (1882-1945) was famous for his engagement with representational maps. He revolutionized the discipline of chart making by finding a way to create picture statistics and quantitative maps that were accessible to a larger public. In this paper however, I will argue that Otto Neurath's map City Planning served not only as one of the first well-accessible socio-political maps of a city, but that it was in effect also a heuristic device.

Originally crafted in color, City Planning (fig. 1, overleaf) was edited to appear in red, black and white, accompanying Neurath's text 'Visual Representations of Architectural Problems', in Architectural Record in July 1937. ${ }^{1}$ The text and the 1937 map were a direct reaction to a similar and in effect more extensive mapping operation pursued by CIAM IV (Congrès Internationaux d'Architecture Moderne, International Congresses of Modern Architecture) in 1933. Nonetheless it was Neurath who first illustrated the socio-political map for urbanism according to graphic rules and with a 


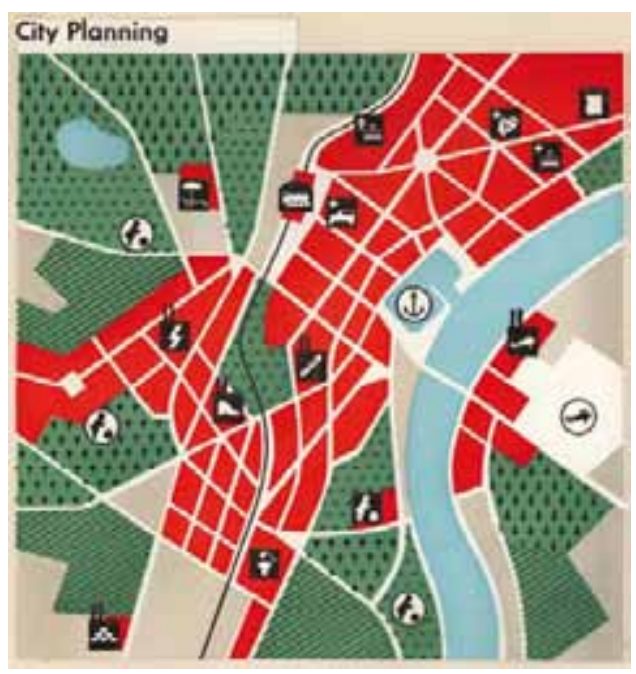

Fig. 1

\section{City Planning,}

Basis to the 1937 Map, 1937, source: Otto and Marie Neurath Isotype Collection, Department of Typography \& Graphic Communication, University of Reading, UK, 5/18 2047.

graphic vocabulary that possessed a consistent logic and even syntax. In addition, I will explore to which degree Neurath perceived of the city as an agglomeration of social facts and in how far his socio-political map contributed in planning the city on such basis.

In order to create this map, three main fields of expertise came into play. First, Neurath's specific views on urbanism were different from those of most architects'. A second necessary expertise to Neurath's undertaking was the ability to graphically craft abstracted data - the transformation, which was invented at Neurath's 'Museum of Society and Economy' (Gesellschafts- und Wirtschaftsmuseum). Thirdly, in search of 'humanizing' knowledge, Neurath hoped that by making information graphically available, he would enable all people to 'participate in a common culture', eliminating 'the canyon between educated and uneducated people.' ${ }^{2}$

CIAM however, was a catalyst for creating the 1937 map as well, in that it triggered Neurath's further research in illustrating the city. When in 1937 his map finally appeared, it marked the culmination of Neurath's search for simplicity in the context of a spatial discussion. The map was however also the last to ever accompany one of Neurath's texts on architecture and urbanism and it ended Neurath's public theorizing of the city, which had lasted for two decades with the exception of the Bilston experiment. ${ }^{3}$ 
Rem Koolhaas's AMO (research unit of OMA, Office for Metropolitan Architecture) is the most prominent architectural think tank promoting the use of the map as tool as well as representational device in a contemporary context. Through their heavy publication activities and their particular architectural wit, $\mathrm{AMO}$ has fostered an interest in mapping that is now found in architecture schools all around the world. Although Koolhaas never cited Neurath, some aspects of AMO's maps are strikingly similar to the ones produced by the Museum of Society and Economy. So when I first decided to assess socio-political mapping and its application to architecture it was precisely to understand this missing piece: how did socio-political mapping in architecture first emerge, which connotations did it possess, which goals did it initially pursue, did Neurath have an influence on the contemporary debate on mapping and if so, how?

\section{Otto Neurath's Urbanist Convictions}

The Austrian Settlement and Allotment Garden Association

The first and most fundamental component to the 1937 map City Planning was Otto Neurath's distinct perception of urbanism. To Neurath the Modern city was an economic organism. But unlike many of the Modern figures in architecture that either rationalized city building by economic means, or subordinated the production of city planning to the economy of the industrialized world, Neurath perceived economic strategies as a means to substantiate a lively urbanism. Neurath's conviction that life in a city could largely benefit from the forces that shaped it, was based on his knowledge of economic relationships.

When Neurath collected images of harbors, grain silos and factories in 1925 for instance, he did not necessarily admire them for their machine æsthetics, as modern architects did at the time. ${ }^{4}$ For Neurath, ports, warehouses and elevated railway tracks represented the global industry, in which he believed lie the foundations for a socially improved Modern city. ${ }^{5}$

What does the city of the future look like? Above all, it is shaped by the modern, large scale industries of global trade. The city of the future is characterized by harbors, railway stations, silos, warehouses, factories, sweeping platforms of elevated traines, and ironworks. [...] But how will the residential dwellings be distributed? ${ }^{6}$ 
Hence, to Neurath the city was an agglomerate of economic relationships and such institutions, and housing maintained a crucial position amongst them. Furthermore, they had to be connected via transportation routes, which he also saw as interwoven with sociological and anthropological components. Cities were spaces where cultural exchange took place, where people met in plazas and in coffee houses, where they demonstrated and went to school, where they were hospitalized, enjoyed a walk in a park, or swam in a public pool. ${ }^{7}$ When looking at urban fabric, Neurath saw it as a unity between architecture and organization. ${ }^{8}$ And he realized this unified vision between architecture and organization when he became the secretary of the 'Austrian Settlement and Allotment Garden Association' (Österreichischer Verein für Siedlungs- und Kleingartenwesen).

During the years of WWI 'wild settlements' had emerged on the outskirts of Vienna, when people in search of food and shelter had started to cultivate small gardens and build provisional barracks. The Austrian Settlement and Allotment Garden Association finally came into existence in the early 1920s to unite the 230 dispersed settlement clubs. Neurath's great achievement was to mend it into an efficient operation while still maintaining the settler's principle of self-help.

Due to his knowledge in economies and organization, Neurath put a system in place that allowed the large building enterprise the settlement movement had become to be governed by three core agendas: economical, political, and educational ones. In particular these agendas were all shaped around the concepts of 'communal economy' (Gemeinwirtschaft) and community (Gemeinschaft). ${ }^{9}$ This meant that the settlers where still involved in building their own houses, even when architects designed them, and that each settler kept 'a piece' of all communal facilities. In addition, educational material was provided within the association to inform and publicize the achievements of the settlers. Often this included extensive exhibitions and magazines.

In comparison to other housing typologies, later pursued in 'Red Vienna', the settlement movement perceived of itself not necessarily as a strictly urban form of living. Houses were rarely higher than two stories - as the chief architect of the Association's Siedlungsamt, Adolf Loos had proclaimed-and they always maintained a close connection to their gardens, where they tilled vegetables. Often houses even had small stables or barns.

It was with the settlement movement that the unity of organization and urban strategies came to full bloom. For Neurath economical and political enterprises truly were as important as the objects - the urban elements - they 


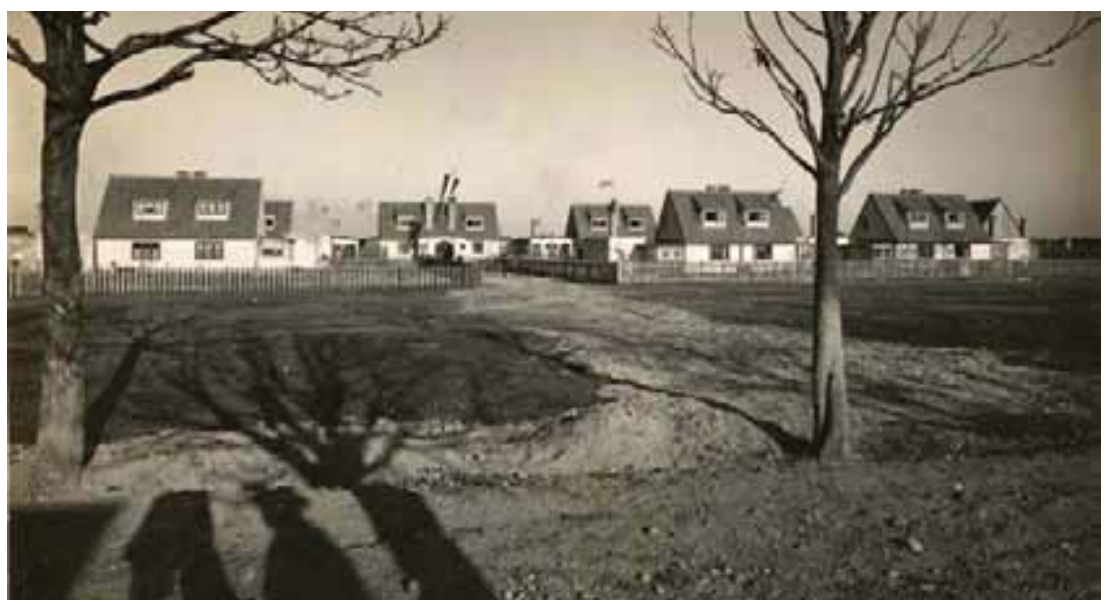

Fig. 2 Shadow looming over new Settler Houses, 1925-1932, source: N-15, N-Files, Otto and Marie Neurath Isotype Collection, Department of Typography, University of Reading, Reading, UK.

created. And the hidden organization that lived behind all elements of a city was also what had to be drawn out and explored in Neurath's 1937 map, and what would take his urban project to a next step.

In terms of housing, Neurath always favored settlements over multi-storey dwellings, but over time his receptiveness to other urban conceptions grew. He started to recognize that settlements could not be employed everywhere, since they were not as dense as the communal projects the city of Vienna started to realize. He also underlined that Gemeinschaft, thus formally articulated differently than in the settlements, was also generated in the municipal dwellings. He wrote: 'In the public dwellings of Vienna's municipality emerges a new common life. The common courtyard serves the play of children, on summer evenings young and old possibly even dance to the sound of the loudspeaker. ${ }^{10} \mathrm{He}$ also noted that the diverse proposals for common living, worked out by many different architects in Vienna encouraged beneficial pluralism. ${ }^{11}$ This notion of pluralism in urban planning was connected with his philosophical perception of coherentism and logical empiricism. Coherentism advanced the idea that truth was a compound of entire systems, but could also be ascribed to its individual propositions. However, scientific 
opinions differed on the question of whether coherentism allowed many possible systems of truth or only a single one. Neurath believed that whatever decision one made 'lay in the 'path of life' chosen by the decision maker.'12

Therefore, a city had to encourage various models to solve problems, so a collective decision could be made by many people on the basis of what they found appropriate for their ways of life and their needs. This attitude foreshadowed Neurath's notion of the purposes of picture statistics. By showing various statistics (aspects of reality) chart by chart, they encouraged their viewer to draw his or her own conclusion.

\section{Otto Neurath's Graphic Gonvictions}

The Search for Simplicity

Since Neurath perceived of the Modern city as an economic organism, he had to find a way to illustrate the 'invisible forces' that governed it. To facilitate this comprehension, which could potentially transgress borders and social status, he strove for a universal language: the language of picture statistics. ${ }^{13}$

In fact, for exhibitions of the settlers a visual chart collection of their achievements was established. In 1925 a permanent Museum emerged from this, soon called 'Museum of Society and Economy' (Gesellschafts- und Wirtschaftsmuseum). This Museum became the home of picture statistics, where the graphic depiction of data was tested and refined.

Most crucial to creating quantitative charts was the role of the transformer - the statistical and graphic personnel that translated data into the quantitative map. Charts at the Museum were not only created according to æsthetic judgment and graphic knowledge, but were also mathematically precise although they were rounded off.

The graphic history of the 1937 map, City Planning, was threefold, since the map consisted of pictograms, patterns made of symbols and spatial parameters.

I.S.O.TY.P.E. (International System of TYpographic Picture Education) symbols usually showed quantities by the repetition of a singular symbol, rather than by scaling in size. While in the 1920s quantitative charts were mainly characterized by arrays of symbols, which actually represented quantities, a main shift occurred in the early 1930s when symbols started to be paired. Until then 'factory' and 'shoe' for example, were represented as two 


\section{田

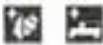 \\ 10 \\ H. \\ 甘光 \\ $\uplus \oplus$ \\ 因 (4.) \\ (f)}
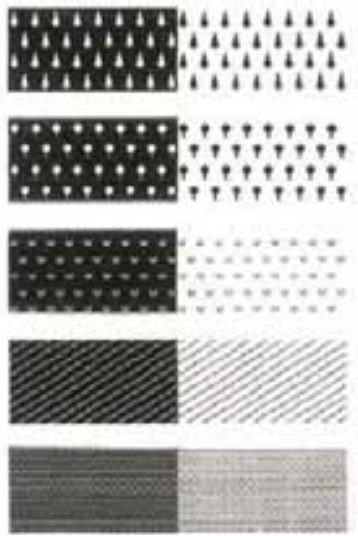

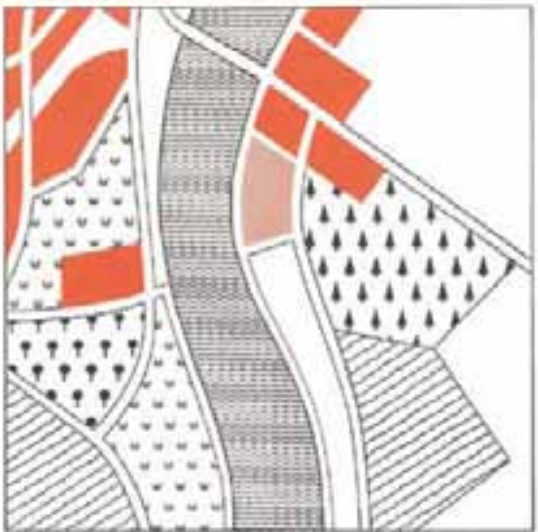

Figs. 3, 4, 5 Main Symbols, 'Various ISOTYPE Symbols', 'Various ISOTYPE Patterns', 'Second Version of a Section of the same (1937) Map', ca. 1937, source: 'Visual Representation of Architectural Problems', Otto Neurath, Architectural Record, 1937, 57-58.

\section{Baumwollwirtschaft der Erde}
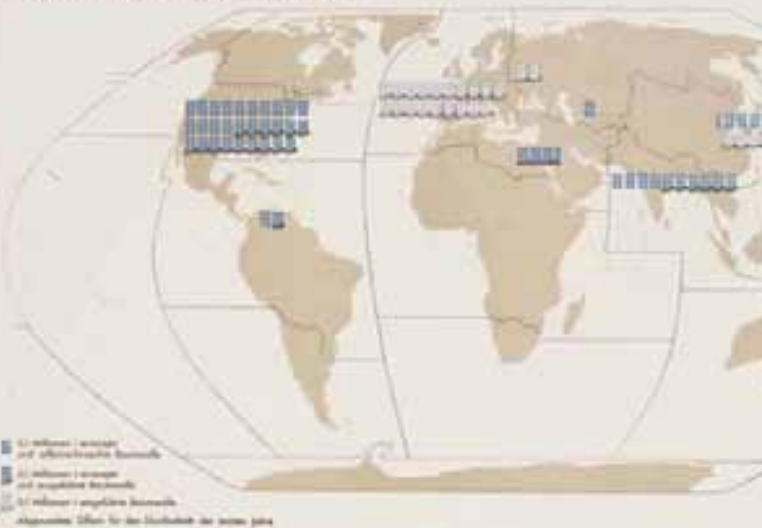

Fig. 6 'Baumwollwirtschaft Chart 44', ca. 1929-1930, source: Gesellschaft und Wirtschaft. 


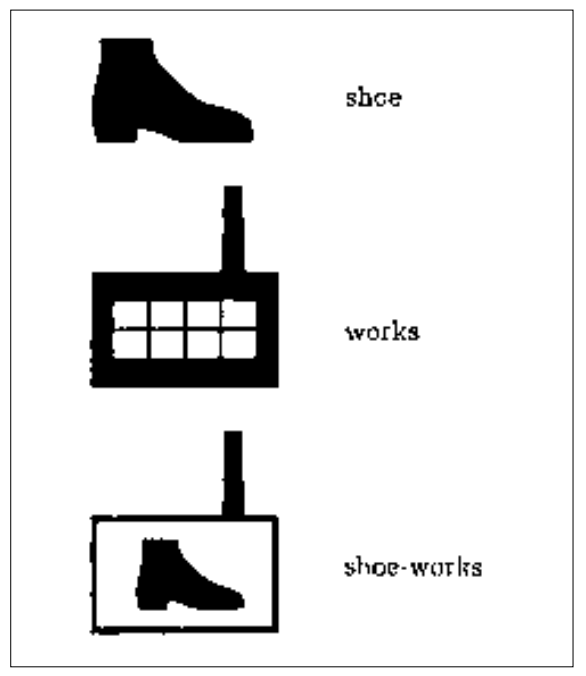

Fig. 7

\author{
Paired Symbols, \\ 'Picture 17' \\ source: \\ Otto Neurath, International Picture \\ Language, Kegan Paul, Trench, \\ Trubner \& Co, London, 1936, 51.
}

separate symbols, had two separate meanings and usually indicated a quantity of shoes or factories when multiplied. By the early 1930s however, symbols started to appear in pairs, and the merge of shoe and factory indicated, 'shoe factory'. This fundamentally added to the nature of ISOTYPE.

While the history of pictograms is well documented in Neurath's writing, the graphic history of the hatches, the second entity employed in the 1937 map, is less clear. From an architectural stand point, they represented a breakthrough because they bridged the symbol to the plan. They allowed the symbol not only to signify quantities within space, but to actually become space when multiplied. They efficiently represented the fabric of rural and urban space to the 'uneducated eye'. Color solids, and technical hatches composed of horizontal, vertical and inclined lines, were employed in other architectural maps at the time, but they were never nearly as comprehensive as Neurath's 'wallpapers', as he liked to call them.

Neurath employed his quantitative maps to depict information in an unbiased way, as done with geographical maps ${ }^{13}$ and his aim was for them to contain a catalogue of universal signs as neutrally as in geographical maps, yet he seldom worked with the actual spatialties of a city. For one, the implications of actual spatialties of the city and their illustration required a degree of technical or architectural craftsmanship that was too complex for the 'ordi- 


\section{Fig. 8}

'Bodem', Gound,
source:
Gerd Arntz Archive,
Gemeentemuseum, The Hague,
Netherlands, Folder 8.

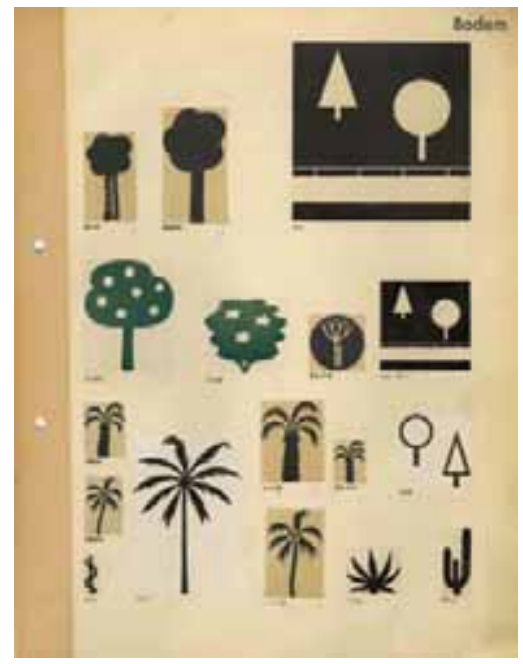

nary man' to decipher. In order to illustrate simple facts Neurath decided to dismiss actual geographical charts and decided to work with cartograms.

In the appendix of Gesellschaft und Wirtschaft Neurath argued that 'the cartographic depiction of the atlas was adjusted to match the picture statistics. ${ }^{15}$ They were intentionally 'not geographical maps, but only cartograms' ${ }^{16}$ Furthermore, the Museums' town plans rarely contained more than one geographical layer, which was also usually highly abstracted. Neurath insisted that quantitative information was to be kept completely separate, once a map reached a more detailed level of abstraction. According to Neurath, town plans should only 'explain the character of a district, but not its exact location or disposition.' ${ }^{17}$

This shows that it was not until the 1937 map that Neurath thought in depth about how to map socio-political factors onto space. Before then, these two layers were consciously kept apart. Pairing layers stood at the end of a long process. Although the segregation of space from statistical information might have fostered better understanding of the chart, it also testifies to Neurath's underestimation of space's dispositions and its resulting complexities.

Since the cartograms consciously followed the laws of the pictogram, they never inherited the properties of a real diagram. Besides Neurath's notion of pluralism the concept of the social silhouette is crucial for investigating Neurath's resistance to spatial praticularities, which are essentially design 


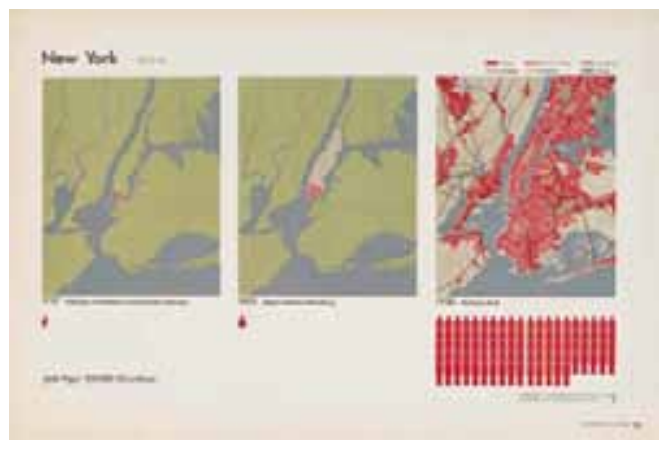

Fig. 9

'New York, Chart 71',

ca. 1929-1930,

source: Gesellschaft und Wirtschaft.

strategies. ${ }^{18}$ The social silhouette promotes that certain aspects of life ought to be only depicted in single charts, so that they do not lead the reader to false conclusions. In The International Encyclopedia of Unified Science (1944) he states:

Various nations have different mortality rates; one cannot say that where the mortality rate is higher, we may also expect a lower standard of public health. It may be that in one nation the percentage of old people is extraordinarily high and, therefore, the national mortality rate may also be very high, even if in all age groups the mortality rates were lower than in other nations. The silhouette of mortality rates would tell us what the situation is. ${ }^{19}$

This is precisely why Neurath wanted to illustrate every single category by itself. Only in their collectivity would the charts create a social silhouette that would show a more holistic picture of social interconnectivities. In contrast to architects, Neurath, the philosopher, could perceive the city as the cognitive construct of manifold social relations that it was. He was freed from the burden of having to coerce it with the specificity that a design task demands.

But it is also for this reason, that Neurath's maps were representational tools, but rarely heuristic instruments. Because only in mapping various spatial aspects within one realm design solutions can be derived.

With the 1937 map Neurath did not mean to arrive at design conclusions, but he did start to map multiple apects in one city plan. In addition, he achieved what he had always wanted and what no architect had accomplished before him: to illustrate socio-economic forces within the city with the same objectivity as the geographical map. 


\section{Otto Neurath's Pedagogical Convictions \\ From Picture Statistics to Picture Education}

Neurath's ultimate goal always was to enable everyone to 'participate in a common culture' and he fought to eliminate 'the canyon between educated and uneducated people. ${ }^{20}$ In this search of 'humanizing' knowledge therefore, graphic education had to be scientifically and pedagogically probed in relation to the intended audience. The vehicle for this refinement became the Museum ${ }^{21}$ - it was where new tools were invented and tested. ${ }^{22}$ And they travelled from there, as exhibitions, catalogs and matrices, to museums and into classrooms.

While the invention of new media for ISOTYPE did not change the language of picture statistics much, they were additional instruments through which this language could be articulated. Concretely, this meant a shift from exhibiting solely quantitative maps on paper, toward providing a set of items that could be used to inform the broad public, ranging from magnetic boards to short films and the Museum itself. ${ }^{23}$ The alteration from using solely charts towards a wide variety of media was also reflected in a change of name: the word Bildstatistik (picture statistics) was replaced by Bildpädagogik (picture pedagogy) better known as Picture Education. Picture Education was also written as P. E. to form i.s.o.ty.P.E. abbreviation. ${ }^{24}$

Between 1925 and 1932 the 'Museum of Society and Economy' started an extensive collection of their own commissioned photographs..$^{25}$ As a result of the Museum's collaboration with Vienna's 'Professional Support Bureau and the Viennese Chamber of Labor' employees at the Museum studied the life of the worker and labor environments meticulously. But staff of the Museum did not only go out to picture work environments, prospective wage earner were also invited into the Museum to gain an overview of various job possibilities. ${ }^{26}$ Progressive sequences - lantern slide shows - of work scenes were also depicted which created a narrative on the duties of the hairdresser, the locksmith, the optician, the tailor, the carpenter, the blacksmith and the factory worker. ${ }^{27}$ These small narratives were headed by a title and a credit slide as well as a 'lead image.'

The most interesting results however were possibly achieved during the Museum's work with students. By the end of the 1920s, picture education became a part of the Viennese school reform. Initiated by the social-democratic government of Red Vienna, the school reform tried to weed out antiquated teaching methods that were considered debris of the monarchy. 


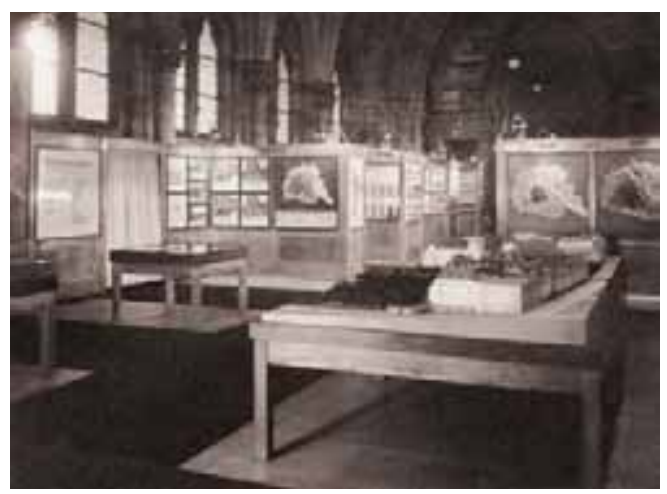

Fig. 10

Media, Relief Chart and Models at Neues Rathaus, Vienna, 1925-1932, source: N-1750 N-Files.

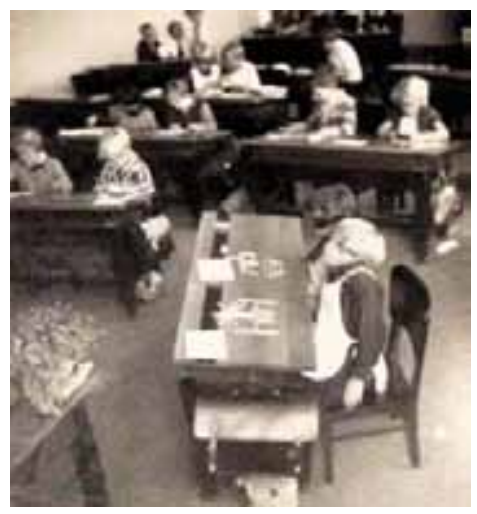

Fig. 11

\section{Children Building Arntz Symbol,}

Vienna, 1925-1932,

source: N-979, N-Files.

The Vienna method was from then on probed in various school types, but mostly in Hauptschulen (middle schools: 10-15 year olds), elementary schools (6-10 year olds) and kindergartens (3-6 year olds). While different teaching materials were used to engage various age groups, drafting of picture statistics was taught at all levels. Surprisingly, this led to the understanding that picture statistics were often more easily appropriated and correctly employed by younger students.

When confronted with drawing the statistical chart, 'How many children stayed at home on the weekend and how many went outside?' Neurath remarked that teens were inclined to solve these problems in an all too detailed and naturalistic way, if the instructor did not specifically request symbolic depiction. ${ }^{28} \mathrm{He}$ attested on the drawings: 
Fig. 12

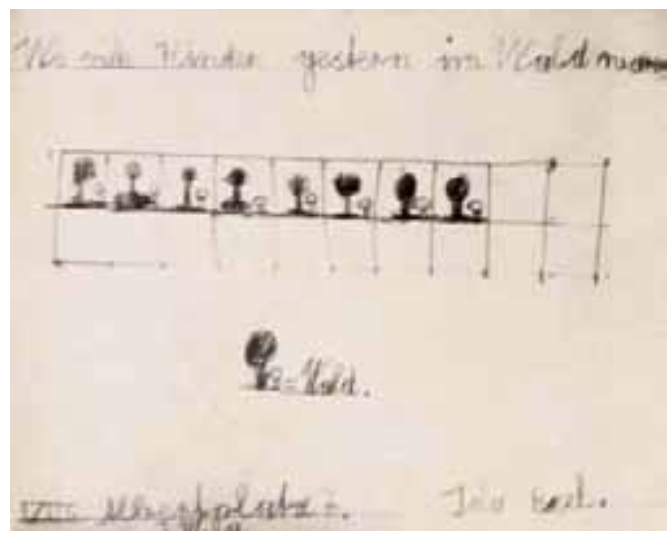

approximately 6 years old, Vienna, 1925-1932, source: N-546, N-Files.

In an all-girls' class, for instance, one will find series: of (drawn) girl-(figures), whose little dresses feature all kinds of details. Braids and such animate the composition. The girls, who stay at home, look outside the window, whose drapes are affectionately drawn out. The lead images give reason for picturesque activity. All too easily they lose the character of statistic free symbolism. ${ }^{29}$

The technique of drawing picture statistics, however, proved apt for children in elementary schools. Research in child psychology had shown that during the years of elementary school and earlier, children were very capable of inventing symbols and designing them in an abstract way. ${ }^{30}$ Neurath attested to this in Bildstatistik und Schule:

In one $[\ldots]$ case a child indicated the 'Sunday in the open-air' with the tree symbol adjacent to a mushroom symbol, omitting [the symbol] of children walking outside. Asked why he chose the tree and the mushroom, he answered absolutely in terms of best picture education: the tree alone could indicate a park in Vienna; with the mushroom it becomes clear that it is a forest. ${ }^{31}$

In general, children quickly grasped the method of drawing quantitative rather than geographical maps. However, ISOTYPE was still not for everybody. Neurath knew and actually intended this. It was not taught in gymnasiums, secondary schools or at universities, it was kept from institutions that drew on the upper class. First and foremost, ISOTYPE was provided to those 
who needed it most, a non-specialist audience. And in this instance, the apparent simplicity of the Vienna Method was unique; because it empowered the weak, it gave the ones who could not read the chance to participate, and it considered the adult just like the child and those with any kind of disadvantage or disability. ${ }^{32}$

When the school material started to travel, so did the Museum's exhibitions. And it was for this reason that some rather famous architects took notice of Neurath and invited him to be the first non-architect member to advise them on how to create a didactic map of the city.

Nobody knew what they were getting themselves into, until after they boarded a steam ship that carried them toward Athens and the most defining congress of architecture and urbanism of the 20th century: CIAM 1933.

\section{CIAM as Catalyst for the 1937 Map Neurath and 'The Functional City'}

CIAM IV, titled 'The Functional City', took place on the cruise ship SS Partis II en route from Marseilles to Athens between July 29 and August 12, 1933.

With the goal to map 32 cities in terms of housing, working and leisure zones as well as routes of transportation, the CIAM architects were drawn to Neurath's expertise on cartograms and they hoped he would help them to enhance their visual language for illustrating the city. Neurath on the other hand was attracted to CIAM as a platform, because it presented an opportunity to launch an interdisciplinary professional language on a large scale. In addition, Neurath was in close contact with the architects Josef Frank and Magarete Schütte-Lihotzky, who both belonged to the CIAM's left wing. Therefore the original CIAM declaration, drafted by one of CIAM's left wing members, resonated with Neurath's understanding of urbanism. It stated:

The idea of modern architecture includes the link between the phenomenon of architecture and that of the general economic system. Town planning is the organization of the functions of collective life; the redistribution of land, the indispensable preliminary basis for any town planning, must include the just division between the owners and the community of the unearned increment resulting from works of joint interest. ${ }^{33}$ 
With CIAM IV however, its left wing became less influential.

The election of the Dutch architect and city planner Cornelis Van Eestern as CIAM's chairman in 1930 was crucial to CIAM politics, because he symbolized the neutral compromise between the opposing (Swiss)-German and (Swiss)French camps. While the (Swiss)-French camp headed by Le Corbusier thought of architecture more along the lines of Fordist production and æsthetics, the (Swiss)-German camp, including Hannes Mayer and Hans Schmidt, perceived the architectural tasks at hand in purely functionalist terms. Some of the left wing camp certainly also dismissed capitalist modes of architectural production. Van Eesteren's mild nature and his will to mediate between different actors contributed to his aptness as chairman.

A further quality that prepared Van Eesteren for the preparations of CIAM IV was his double role as architect and urban planner. In 1929 we was called to serve in the Urban Development Section of Amsterdam's Public Works Department where he started to work on an extension plan for the city. For this purpose he drew out maps generating a comprehensive design strategy. Since Van Eesteren had completed three model maps for the city of Amsterdam, it was sensible to use their logic and organization as the basis for maps of 'The Functional City.' ${ }^{34}$

The first map in 1:10,000 sought to show existing conditions in a city, recording industrial and housing zones, as well recreational areas. The second map, drawn at the same scale, analyzed transportation networks, and the third, at 1:50,000, captured 'the city in its regional setting, including areas of public and private open space, and additional information on all four [Corbusian] functions of dwelling, work, recreation and transportation. ${ }^{35}$

Van Eesteren created the model maps and 72 symbols that would help clarify the given information. At a preparatory meeting in Berlin, during which the Berlin Building Exposition took place, a contribution of the 'Museum of Society and Economy' received special attention from the CIAM members due to its comprehensive designs. It was then that Sigfried Giedion suggested collaborating with non-architect specialists for CIAM IV, namely Otto Neurath. ${ }^{36}$ Although preliminary meetings between Neurath and Van Eesteren had taken place before 1933, Giedion notified Neurath to join the congress on the Patris at last minute.

Van Eesteren had done his best to develop a comprehensive graphic system in preparation of the congress. He was, however, unable to unite his 72 symbols in a coherent way and mixed conventional architectural drawing 


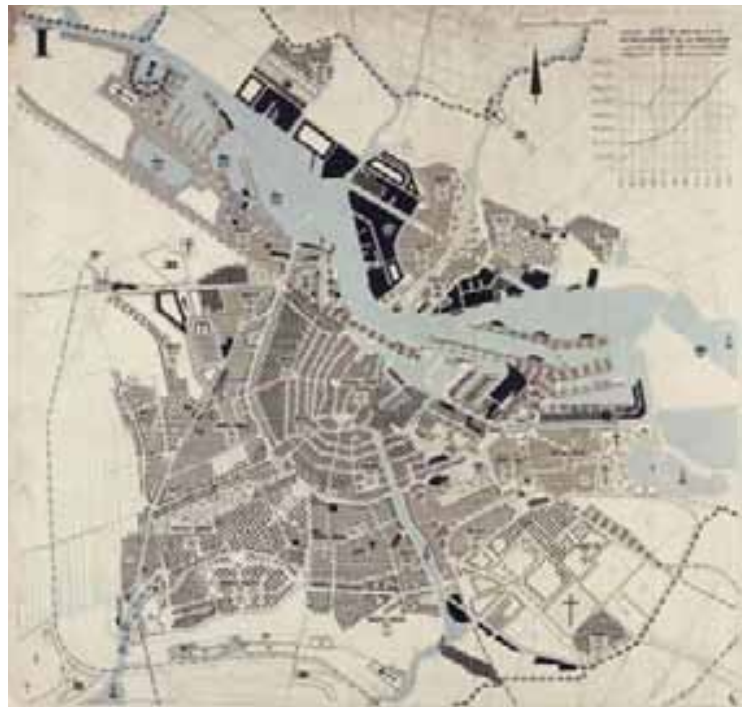

Fig. 13

\section{'CIAM Model Map I',}

Cornelis Van Eesteren,

CIAM, 1931,

source: gta Archive,

CIAM Archive, ETH Zurich.
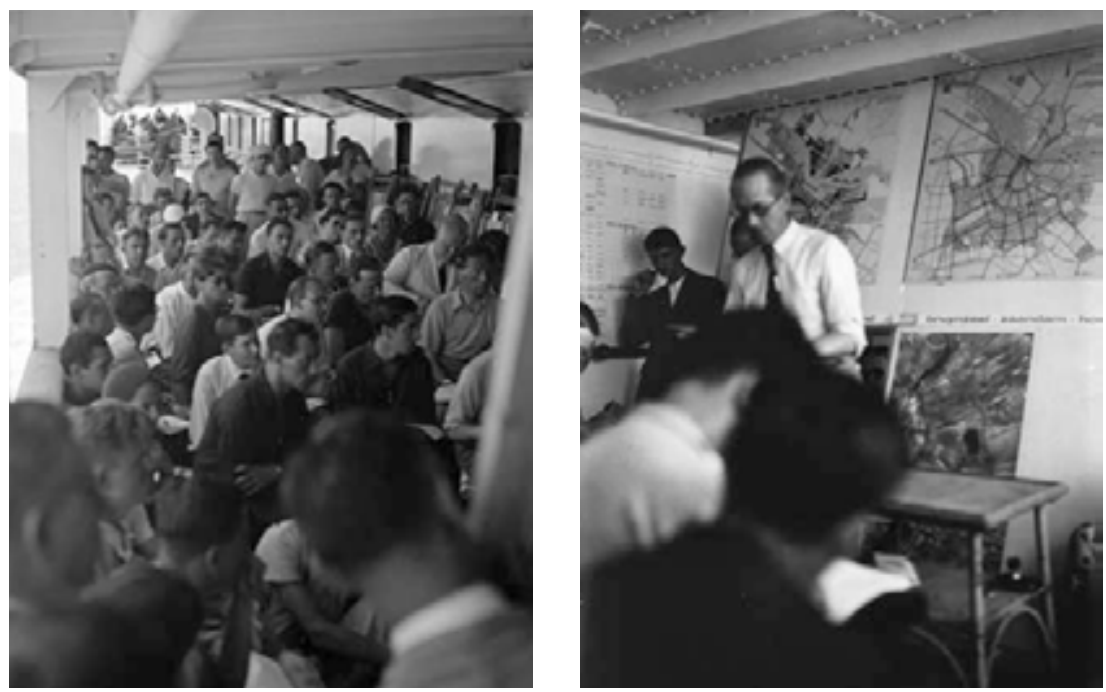

Fig. 15

Fig. 14

Le Corbusier on Board of the Patris,

CIAM Delegates on Board of the Patris, 1933, source: gta archive, CIAM Archive, ETH Zurich. Background, Three CIAM Model Maps, 1933, source: gta archive, CIAM Archive, ETH Zurich. 
Fig. 16

Sigfried Giedion and

Otto Neurath, 1933, source: gta archive, CIAM

Archive, ETH Zurich.

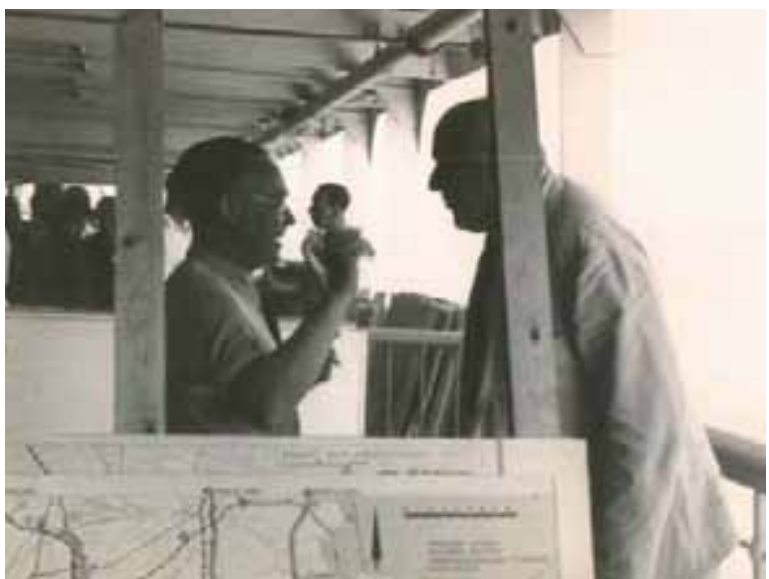

methods with symbols. Therefore Van Eesteren hoped that Neurath's speech would clarify certain graphic hurdles. This was especially important since the beginning of a publication of CIAM's maps was anticipated as soon as the CIAM delegates would return from the Congress. Neurath's speech was held in Athens on August 4, where the maps were exhibited at the Athens' Polytechnic University.

The Patris left Marseilles on July 29, 1933. The first three days on board were dedicated to discussions and analyses of the delegations' maps. Le Corbusier held an introductory speech, addressing the question of how the maps could achieve at concrete conclusions.

The next day, Cornelis Van Eesteren addressed the relationship of effective illustrations of urban analyses and their translation into design proposals in his speech 'Methoden des funktionellen Städtebaus (Methods of Functional City Planning)' ${ }^{37} \mathrm{He}$ explained how data had been extracted and to which urban proposals these analyzes led. He accompanied his lecture with the extension plan for the city of Amsterdam as an example.

On the collection of data, he said:

In the extension plan, one only has to take into consideration the entities that require an advantageous position in relation to the entire body of the city. These are the objects that appear insular in every city: hospitals, mental institutions, cemeteries, crematories, etc. ${ }^{38}$ 


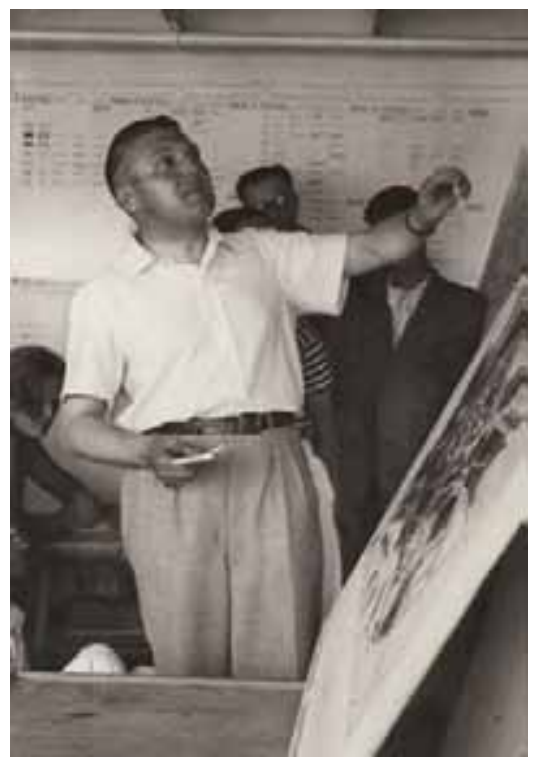

Fig. 17

Cornelis Van Eesteren, In the Background his Symbols, 1933, source: gta archive, CIAM Archive, ETH Zurich.

But he also stated:

On the basis of technical details, like railways and shore connections, solutions were found and extensive reports were drafted. For the expected population a prognosis was made and a minimum as well as a maximum were determined, for both cases the plan should propose housing possibilities. ${ }^{39}$

His speech was followed by Neurath's 'L'urbanisme et le lotissement du sol en representation optique d'après la méthod viennoise' (Town Planning and Lot Division in terms of Optical Representation Following the Viennese Method)..$^{40}$ Neurath's answer to mapping densities in a city was still what he had always pledged: they should not be mapped into the drawing, but they should be shown in a separate supporting chart. Presenting the image 'Men Living on a Unit of Space in Town', he reiterated:

If one wants to show the density of inhabitants in the large cities of the world using our method, they would be characterized by monuments, for example, Paris by the Eiffel Tower and Notre Dame, London by the bridge over the 
Thames, etc. The population density will be represented by black or colored figures. At first glance, one will notice that while in Anglo-Saxon cities, for example, there are fewer inhabitants per 100 square meters than in the cities of Central Europe. I do not enter into considerations of whether dwelling in one- or two- floor buildings determines this situation. ${ }^{41}$

This solution was of course disappointing to the architects, because it did not allow for density to have a spatial implication. Neurath also insisted that actual maps did not even have to be drawn up at all and that cartograms served the cause of mapping the city even better than maps with spatial precision.

It is not always necessary to show these graphics on geographical maps; it often suffices to use geographical diagrams. The diagram facilitates observation. I think that we could better represent many facts studied at this congress through similar diagrams [to the ones I've shown] rather than through plans or geographical maps. ${ }^{42}$

To some, this statement must have felt disconcerting, since they had spent days and weeks in preparation of their precise city maps.

At last Neurath showed plans on the city development in Damascus, produced for the Atlas Gesellschaft und Wirtschaft in 1930, to illustrate the topic of the Congress more closely. These maps were however lacking any kind of paired information like combinations of spatial implications and symbols, or implied socio-political and demographic data.

But Neurath's speech, despite its lack of new insight, was of course accurate in its criticism of the CIAM maps. It identified their shortcomings by calling out their lack of a uniform system of symbols. Furthermore, it pointed out that they were not apt for the public at large. To remedy this, Neurath suggested the usage of wallpaper cut outs and symbols on paper, which schools had been able to order through the Museum.

Although Neurath's speech was disappointing, he was elected to serve on various committees and a collaboration between CIAM and the Museum in Vienna was planned before returning to Marseille. On August 12, upon arrival in Marseille, a first meeting of the publication commission, consisting of Van Eesteren, Sigfried Giedion, László Moholy-Nagy and Otto Neurath took place. Earlier the English delegation had questioned the 'scientific 


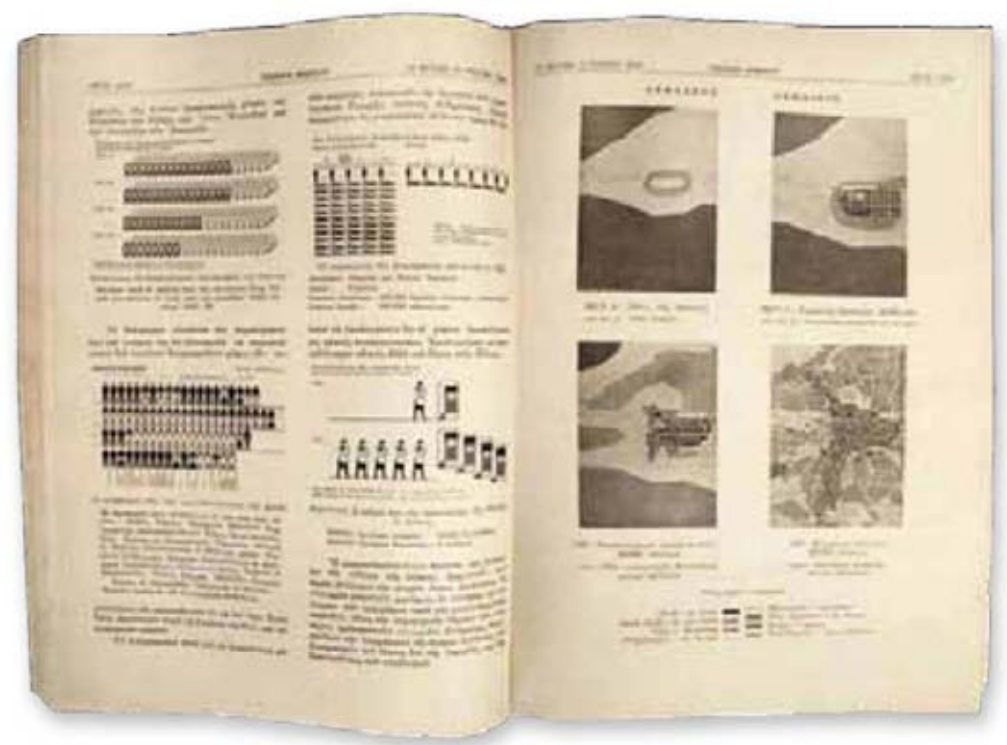

Fig. 18 Left Hand: Charts of Damascus, ca. 1929-1930, source: Technika Chronika, gta archive, CIAM Archive, ETH Zurich.

legitimacy' of CIAM's resolutions, which also affected this first meeting.

For Neurath illustrating CIAM's resolutions was a chance to spread his international language of signs widely. Therefore he wanted to rework some of the Congress' material. Giedion's idea, however, was that only the Congress material should be used, so that the Congress could proceed faster. This caused a dispute between Neurath and the architects.

Neurath, on one hand, advised that the resolution should be shown in simple statements with newly produced fragments of plans illustrating the resolution's singular focal points. ${ }^{43}$ Moholy insisted that CIAM's maps were 'impressive' and best displayed the resolution's origin as well as its process. In conclusion, the commission decided that a small publication should contain the resolution with 'images and explanations' and that the larger publication required 'in depth reassessment with perfect optical representations'. ${ }^{44}$

In the near aftermath of the congress, Neurath was eager to get to work. Van Eesteren, however, wrote a letter to Moholy-Nagy confessing that he was really happy Moholy had 'so actively participated in the congress', in particular 
in a conversation with Neurath, because otherwise they 'would have certainly fallen victim to his rather limited system' ${ }^{45}$

An upheaval occurred in November of 1933, when Neurath was notified late of the second get-together in Paris. He issued a short letter to Le Corbusier's CIRPAC (Comité international pour la résolution des problèmes de l'architecture contemporaine) voicing his discontent. ${ }^{46}$ When he did not hear back from CIRPAC for three weeks, he finally decided to confide in Van Eesteren: 'Please tell me how all of this should be understood in your opinion. If prominent members of your CIRPAC do not attach importance to the collaboration with us, I would prefer to withdraw my institute, but not without maintaining a personal friendly memory of you and your kind way of conduct with us. ${ }^{47}$

Nobody replied to Neurath until five months later. During this time Van Eesteren was serverly sick. When he finally wrote back in May of the following year, he stressed, however, that as soon as Neurath made concrete suggestions on the basis of the plan of Amsterdam, he would still present these results to CIRPAC. ${ }^{48}$ A meeting between Van Eesteren and Neurath followed this letter.

During the months of Van Eesteren's sickness, Neurath had his own problems. In the winter of $1933 / 34$, he left Vienna for a visit at the 'Isostat' in Moscow. In February, the Austrian Civil War broke out. Representatives of the Viennese social democratic government and those affiliated with it were imprisoned. When the police came to search Neurath's office at the 'Museum of Society and Economy', Marie Reidemeister warned Neurath not to come back to Vienna and they arranged to meet in Prague, from where they immigrated to Holland and finally settled in The Hague.

Van Eesteren was honest in giving Neurath a second try in 1934. In a letter to Giedion, issued a couple of days after his meeting with Neurath in Amsterdam in May, he wrote that he was still of the opinion that 'something must grow' from the collaboration between the congress and Neurath..$^{49}$ Concretely, he thought of the exhibition 'The Functional City' that he planned to show in Amsterdam where the next CIRPAC meeting would take place. He still hoped that Neurath could advance his symbols for city planning.

In preparation for an exhibition titled 'The Functional Gity' which was held in Amsterdam in 1935, Neurath's interest and Van Eesteren's enthusiasm for the collaboration rekindled. They met frequently between October 1934 and February 1935. Neurath tried to work on the symbols and maps, indentifying some of the major spatial problems. 'One should possibly combine 
density of population, number of apartments, floor heights etc. [by means of symbols]' Neurath wrote. ${ }^{50}$

The final death blow to the collaboration came with a presentation Neurath gave for the architecture collective 'de 8' which included Van Eesteren. The meeting did not draw much attention and many architects left displeased with Neurath's speech. ${ }^{51}$ Neurath on his part, was highly disappointed that Van Eesteren did not show up. He wrote a last letter stating that he was very sorry about his absence, because Van Eesteren 'was always so mediating.' ${ }^{52} \mathrm{He}$ concluded: 'Everything can be solved given some consideration, but neither is it only a graphic task nor is it solely that of an architect; it requires an intermediary ... TRANSFORMATION ... But this is an old song I have already whistled and jingled to you in different variations. '53 'The Functional City' exhibition in Amsterdam opened in July of 1935. Neurath was never credited anywhere, although some charts were modeled after his suggestions.

Why did this collaboration between Neurath and CIAM fail so catastrophically? For one, Enrico Chapel has very precisely assessed the complication of Neurath targeting a different audience than CIAM. He stressed that from the beginning, Neurath and the CIAM architects aimed at diverse target groups and they also 'expected totally different reactions. ${ }^{54}$ Chapel continues:

Neurath invented his system within the framework of a global visual communication programme, with a view to 'humanize' knowledge for the greater benefit of the general public; the architects sought to internationalize an established body of knowledge; their principal targets were the decision-makers in the field of urban production..$^{55}$

This is certainly relevant, since Le Corbusier for example conceived of the purposes of CIAM IV transnationally. This 'meant working closely with large interests with the capital to implement his overarching vision of social and architectural transformation' as Mumford has argued in his CIAM Discourse on Urbansim. ${ }^{56}$ But in general the architects wanted to pride themselves with their technical expertise and with the fact that they had found the means of representation that were specific to their discipline. Again, Enrico Chapel has put it precisely in saying:

In the first place, one should not underestimate the difficulty of applying a pictorial method that was not designed with town planning in mind $[\ldots]$ 
This system, which visualized social phenomena and economic data, failed to account for a whole range of dimensional and more generally spatial parameters, which are nonetheless indispensable to any study carried out prior to the intervention of urban space. ${ }^{57}$

Kees Somer supports Chapel's assessment in stating that the CIAM architects saw their maps 'as practical instruments' and 'their attention remained focused, on the reality of urban planning, which they had investigated with an immediately operational purpose: the improvement of the planning and design of the environment in which people live. ${ }^{58}$ These observations are crucial because they precisely describe the difference between the map as an architectural heuristic device and the map as representational medium: and this is the divide that could not be overcome by Neurath and the architects in the framework of CIAM IV.

\section{The 1937 Map-City Planning From City Planning to Architectural Record}

In 1937, two years after the end of his failed collaboration with CIAM, Neurath published his first socio-political map of a town, originally titled City Planning. The title is more charged than one might assume at first glance, as it suggests a concern with actual 'planning' rather than just a sober analysis, which would have been the typical mode of operation for Neurath.

The great breakthrough of the 1937 map was the overlap of spatial parameters with hatches and pictograms. This overlap was certainly missing in the map of Damascus that Neurath had presented on the Patris, and it was also missing in all his quantitative charts of the world. While the ISOTYPE symbols presented altered concise syntax, the 1937 map also effectively clarified how to successfully employ 'wallpapers' and how to abstract spatial implications. In fact, the 1937 map was one of the first that mapped space with precision, which eventually enabled it to show first traits of the map as architectural tool.

Admittedly, when comparing Neurath's map to Van Eesteren's model map I of Amsterdam, Neurath's approach in mapping the city still looks relatively abstract. But given a closer reading it becomes apparent that Neurath actually managed to supersede Van Eesteren's approach in creating an insightful tool. 


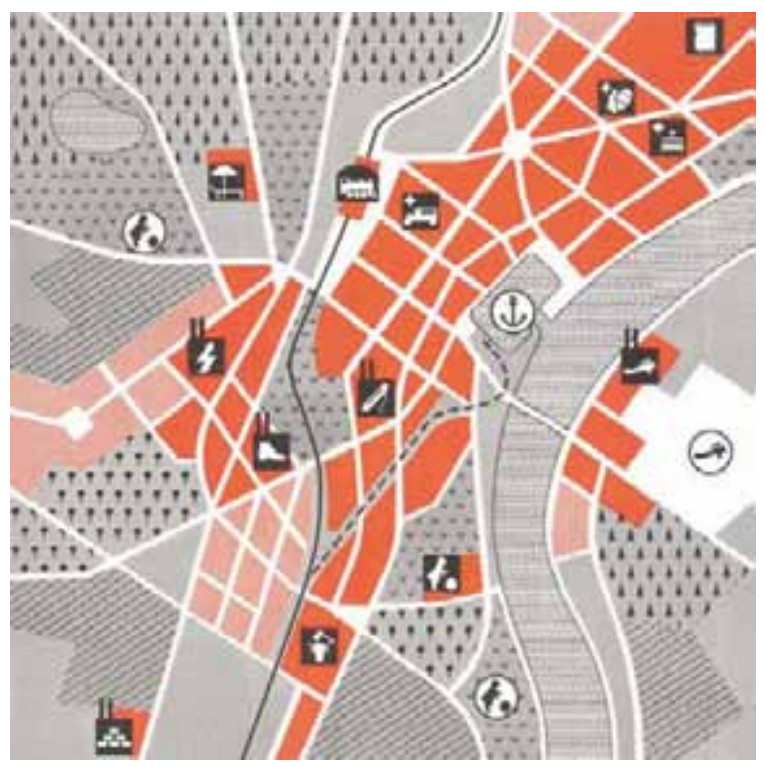

Fig. 19

The 1937 Map, 1937, source:

Architectural Record, July, 1937, 56.

Among CIAM's three model maps, model map I of Amsterdam lends itself best to a comparative study, because it depicts existing conditions in a city and accounts for housing, work and leisure zones in a manner closest to the content of Neurath's map.
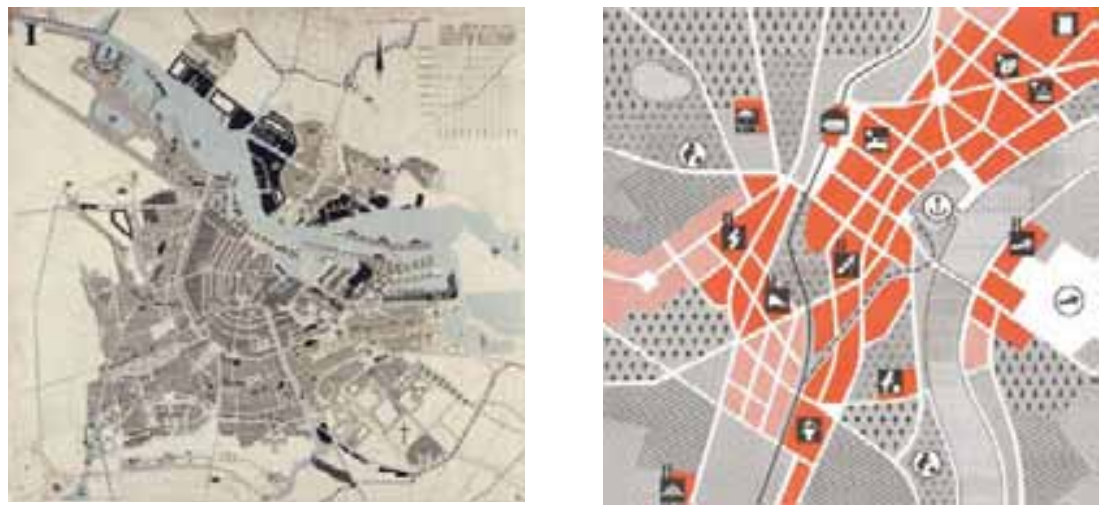

Fig. 20 'CIAM Model Map I' and 1937 The Hague Map Comparison 
In a first and most obvious instance Neurath's hatches are more developed than Van Eesteren's. ISOTYPE hatches could be inverted due to their simplicity and indicate two different, but clearly speled out things in one map. Van Eesteren's hatches on the other hand employed a multitude of different manners of hatching, so that his charts became impossible to read without an index.

The indication of density was not successfully addressed by either map. Van Eesteren used numbers to indicate additional social factors in the plan, but they did not provide a general understanding of the relationship between statistics and space. Neurath, on the other hand, did not even try to address this issue, since he stayed true to his principle that quantitative information should be kept separate from the map. Architects who are always closely connected with making floor plans and maps mostly intend to show social facts on maps, but in a great many cases we have to give preference to other methods of representation', he criticized in Architectural Record. ${ }^{59}$ In his text Neurath reiterated this by showing density charts of different cities, something he had already demonstrated on the Patris by the example of Damascus.

On a second level, the comprehensiveness of Neurath's symbols was also greatly improved, since a way was found to differentiate various types of buildings by simple means. Houses, factories, and big halls like railway stations could be distinguished by the basic shape of their symbols. Whether a space was located outdoors or indoors was indicated by black and white backgrounds. ${ }^{60}$ In addition, Neurath gave his symbols a background so they could be read as a symbol only. He also showed them in elevation, which made them clearly more abstract and identifiable as a symbol.

Van Eesteren's symbols on the other hand, are 'driving' or 'floating' in all kinds of directions, which makes the plan very literal. In addition this makes it difficult to understand what the symbols imply: is this a real ship or is this an area for ships?

And thirdly, there was the issue of spatial abstraction, which had always been Neurath's weak point. When analyzing Neurath's map the discrepancy in scale is unsettling. The map seems to depict an urban environment and it indicates urban institutions (hospital, factory) yet the size of the city seems too small, too trimmed, to be an actual city.

Unfortunately Neurath did not often discuss maps individually, in fact there is no hint in the literature that the 1937 map derived from a real city. The general assumption has always been that it is a generic representation. 

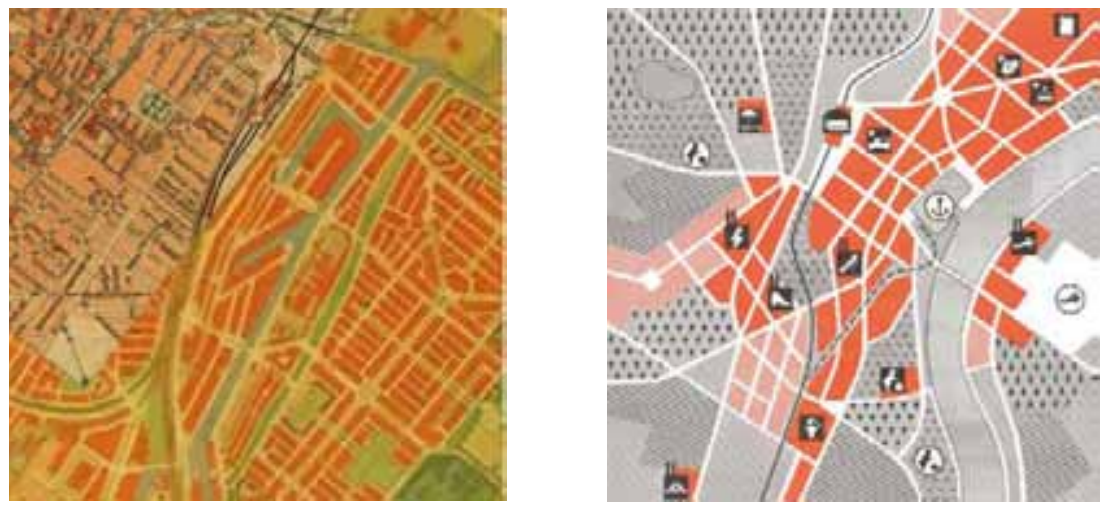

Fig. 21 The Hague 1930 and 1937 Map Comparison

This is logical, since Neurath argued for years that rules in city planning were best illustrated by means of showing small generic parts or cut-outs. Yet, how does one illustrate a generic city or invent a city from scratch? This would seem to be a fairly complicated task for someone who had no such specific training.

What counters the generic theory is that Neurath usually drew from actually found social and economic facts. So why would he make an exception with the city? Why would he not treat the city as a spatial social fact? In addition, the 1937 map clearly seemed to be 'Neurath's attempt at [contrasting] the language of "The Functional City"' and that would suggest working with an actual city. ${ }^{61}$ After all, CIAM specifically set out to map more than thirty actual cities in the world. But as for being the illustration of a real city, the 1937 map was too out of proportion, and as generic it was too specific.

It seems that to some extent both theories are applicable: The 1937 map is indeed generic, but there is reason to believe that the generic cut-out was drawn on the basis of a significant city. It was a city meaningful to Neurath, a city that made sense in contrast to Van Eesteren's Amsterdam, namely The Hague, Neurath's new city, the city where he continued his legacy.

It seems that in the end Neurath realized that spatial givens were important to take into consideration, even when depicting the city. However, he kept this realization a secret, because it was most important to emphasize that such 


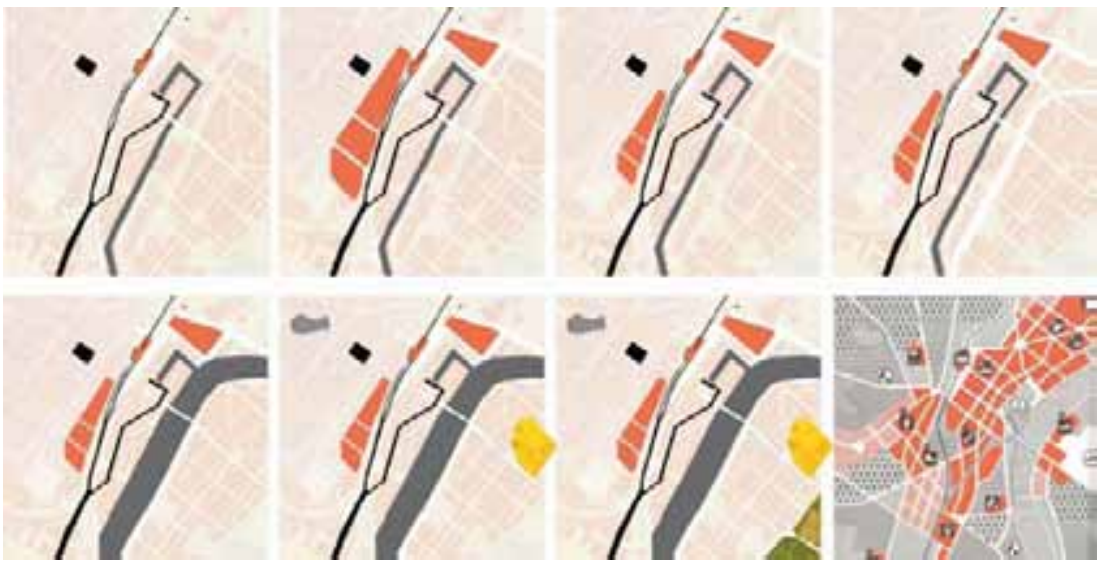

Fig. 22 Transformation, all figures drawn on the basis of the 1930 plan of The Hague, 2010, source: Sophie Hochhäusl.

infrastructure could exist with slight differences in every city in the world.

In order for the map to be a valid response to CIAM it needed to be a place that possibly incorporated all aspects of 'The Functional City'; housing, workplaces, recreational areas and various transportation networks. Obviously, such a place was hard to find in only a small cut-out of a city. Therefore modifications had to be made: spatial transformations.

The charts above, first depicting an actual plan of The Hague and lastly depicting the 1937 map, suggest that the trained statistical transformers were able to transform the particularities of space. They seem to suggest that from the actual city, a good transformer would move on to draw out a larger city block and scale it down. Then the transformer might morph a river into a sidewalk and some housing blocks into a river. The transformer might also copy an airfield from the far south of the city and insert it straight up north into the fictional city, where it fit best alongside a major transportation route. Then, he might also do the same with a lake from the outskirts of the city. Finally, the transformer could start drawing out actual greenery in the city. He might also invent some greenery and reshape some housing blocks and move them to where they fit best. And if he is a gifted transformer, he will eventually arrive at a generic city.

The combination of spatial implications and socio-political factors alone was one big step, but to actually work on the basis of a real city while at the 
same time making such spatial transformations signifies one step towards the operative. Van Eesteren was never able to improve his symbol dictionary despite his dedication. Neurath alone did make a step forward: he started to develop his first and last map of a city and moved toward city planning.

But let me be clear: Neurath never did one thing: he never combined quantitative and spatial maps. That would have been a too suggestive move, inviting seductive design conclusions and singular decisions. So when the question was posed in the beginning if Neurath perceived of the city as an agglomeration of social facts, then the answer is yes, he did. He believed that these social institutions in a city could and had to be mapped in the city, that in fact they needed to be drawn out so that people could come to an understanding of their built environment. But still, he never thought of the maps, as means of making precise design decisions.

Nonetheless he illustrated in the generic map of The Hague a city how he envisioned it: as small town by the water, fifty percent greenery, fifty percent urban fabric, possibly reminiscent of the Viennese settlement movement. But Neurath also stressed the city's important institutions: working areas and leisure zones, hospitals, kindergartens and playgrounds as well as factories. And they were integrated in housing zones, in great contrast to how the CIAM architects had envisioned the city during CIAM IV. More than only creating an altered illustration of the city, Neurath also represented a piece of the city as he projected it.

Neurath referenced the CIRPAC in this text only once, in a footnote. He stated that ISOTYPE standardization could be compared 'with various attempts at architectural representation, e.g. with the stimulating proposals of the CIRPAC made by Van Eesteren. ${ }^{62}$ It is unclear if that mention was really meant as a tribute to the 'stimulating proposals', or if it was meant to parallel his own work to that of CIAM, mention of it, he might have felt, was long overdue. 


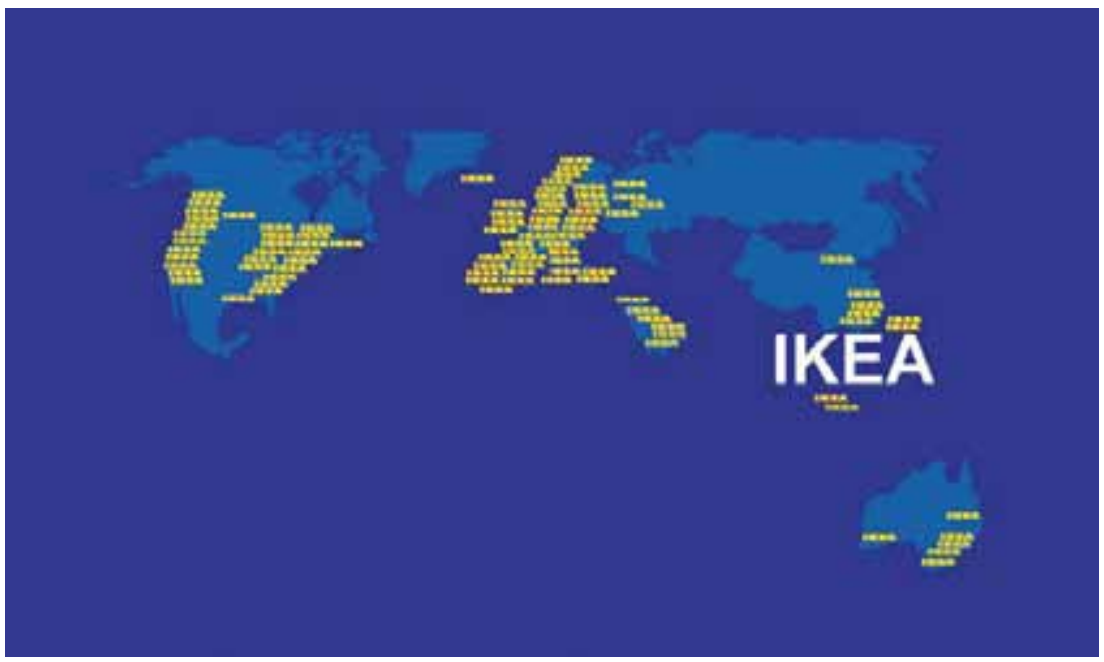

Fig. 23 World of IKEA, Image courtesy of AMO.

\section{Postscript}

In an interview conducted for this research on Neurath, Rem Koolhaas confirmed that he was familiar with the work of Arntz and Neurath and that he had been influenced by it. On occasion AMO's maps even seem to have much in common with Neurath's maps, although AMO's certainly uses both, operative maps as a means of design, and those that communicate precise statements about the world.

'But doesn't a liquid, completely globalized world, also require more liquid maps?' I asked Koolhaas during the interview, 'ones that apply a fundamentally different logic, than the ones from the 1920s and 30s.'

'How would you imagine that?' he asked me. 'Are they in real time, are they alive?' And then he answered:

The promises of the digital are short-lived. In many cases before the promise can establish itself, the decadence of it already prevails, or the commercial prevails, or the trivial prevails. It has been an incredibly difficult domain in which to retain precision and to retain integrity. In certain cases exactly against this fluidity and against this immediate abuse of every idea, that the Internet $[\ldots]$ 
seems to suggest, [we create maps that are] at least momentary freeze frames of particular conditions. ${ }^{63}$

'I think we [make maps] ... as interpreters at a moment of great political and ideological confusion' Rem Koolhaas said at the end of the interview. 'To some extent we adopt a language, not so much ironically, as a statement that there once was clarity, but the clarity is currently gone.'

Sometimes I wonder what Neurath and Van Eesteren would say if they saw that today 'their maps' have finally been altered for making precise statements, while at the same time being effective design tools. I think they would be very satisfied. Only Otto Neurath might ask Rem Koolhaas, about his ultimate purpose. 


\section{Notes}

1 Otto Neurath, 'Visual Representation of Architectural Problems', Architectural Record, July 1937: p. 56-61.

2 Otto Neurath, 'Visual Education: A new Language', Survey Graphic (1937): 25. 'When will the Middle Ages be at an end? As soon as all men can participate in a common culture and the canyon between educated and uneducated people has disappeared.'

3 Sybilla Nikolow, 'Planning, Democratization and Popularization with ISOTYPE, ca. 1945. A Study of Otto Neurath's Pictorial Statistics on the Example of Bilston, England', Induction and Deduction in the Sciences, Vienna Circle Yearbook 11 edited by Elisabeth Nemeth and Friedrich Stadler (Dordrecht, Boston and London: Kluwer Academic Publishers, (Dordrecht: Kluwer Academic Publishers, 2003), 299-329.

4 These are all photographs of other photographs or publications that Otto Neurath collected in the N_Files. These are N_421, N_425, N_430. ISOTYPE Archive, Department of Typography, University of Reading, Reading, UK.
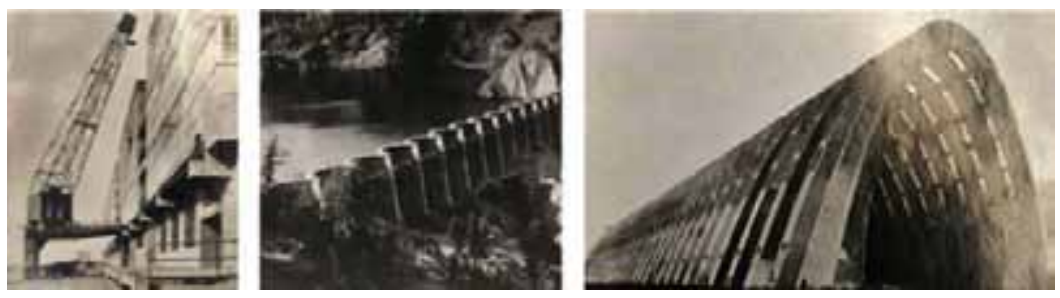

5 Otto Neurath, 'Städtebau und Proletariat', $\operatorname{Der} \operatorname{Kampf,~(1923):~} 240$.

6 Otto Neurath, 'Städtebau', 240. 'Wie wird die kommende Stadt aussehen? Vor allem arbeitet an ihr die moderne, großorganisierte Industrie, der weltumspannende Handel. Hafenanlagen, Bahnhöfe, Silos, Lagerhäuser, Fabriken, kühn geschwungene Hochbahnen, Eisenkonstruktionen kennzeichnen die kommende Stadt, Wolkenkratzer recken sich stolz empor, an bestimmten Stellen durch bestimmte Zwecke bedingt, einem Gesamtbild unter Umständen durchaus harmonisch eingefügt. Wie aber werden die Wohnungen verteilt sein?'

7 Otto Neurath, 'Städtebau', 240. 'Es geht darum, nicht nur die Industrie- und Wohnbauten richtig zu verteilen, Wohnungen mit den Verkehrswegen richtig zu verknüpfen, es geht auch darum, das so Geschaffene architektonisch harmonisch zusammenzuführen, die Stadt als eine einzige architektonische Einheit anzusehen!'

8 Otto Neurath, 'Städtebau', 240. 'Was für Architekturideen leben nun in den 
Architekten und Organisatoren, was für Architekturideen werden von den breiten Massen aufgesogen?'

9 For a detailed discussion on the notions of Gemeinwirtschaft and Gemeinschaft see Nader Vossoughian's chapter 'Community', in Nader Vossoughian, Otto Neurath: The Language of the Global Polis (Rotterdam: NAi, Punlishers 2008)

10 Otto Neurath, 'Kommunaler Wohnbau in Wien?', Die Form (1931), 52. 'In den Volkswohnungsbauten der Gemeinde Wien beginnt ein neues Gemeinschaftsleben. Der gemeinsame Hof dient dem Spiel der Kinder, an Sommerabenden tanzt Groß und Klein wohl gar nach den Klängen eines Lautsprechers.'

11 Otto Neurath, 'Kommunaler Wohnbau', 52. 'Die Neubauten zeigen die verschiedensten Formen, wie sie eben entstehen, wenn in toleranter Weise die breiten Scharen der freischaffenden Architekten sich betätigen können ... .'

12 Andreas Faludi. 'Otto Neurath and Planning Theory', in Encyclopedia and Utopia, The Life and Work of Otto Neurath (1882-1945), edited by Elisabeth Nemeth and Friedrich Stadler (Dordrecht, Boston and London: Kluwer Academic Publishers, 1996), 208.

13 Otto Neurath, 'Die pädagogische Weltbedeutung der Bildstatistik nach Wiener Methode', Die Quelle, (1933): 209. 'Die internationale Bedeutung dieser Methode beruht unter anderem darauf, dass wie die Erfahrung zeigt, die gleichen Bildertafeln in verschiedenen Ländern verwendet werden können. Die Bilder sind geeigneter als Worte, eine Menschheitskultur vorbereiten zu helfen. Worte trennen - Bilder verbinden.'

14 Otto Neurath, 'Autobiography', 100. 'When controversial problems are presented in print, people expect some kind of bias from the outset, in a way which they would not expect from looking at geographical maps. Isotype is bound to be as neutral as maps and to provide material for free discussion from any point of view. Isotype symbols have fewer positive or negative associations than the printed or written words of a language. You cannot write in a neutral way without being boring, but you can present a neutral picture which is nevertheless attractive.'

15 Otto Neurath, 'Grundsätzliches zur Kartographie': Gesellschaft und Wirtschaft, Bildstatistisches Elementarwerk, (Leipzig: Bibliographisches Institut A. G., 1930): 102.

16 Otto Neurath, 'Grundsätzliches', 102. 'In diesem Bildstatistischen Elementarwerk gibt es keine geographischen Karten, sondern ausschließlich Kartogramme, um Eintragungen vorzunehmen oder bestimmte Tatsachen zu veranschaulichen.'

17 Otto Neurath, 'Grundsätzliches', 102. 'Auch die Stadtpläne sollen nur den Charakter der Stadtteile, die Verschiebungen der Lage kennzeichnen, nicht aber genaue Lokalisierungen ermöglichen. Die kartographische Darstellung des Atlas wurde 
ausschließlich der Bildstatistik angepasst.'

18 Otto Neurath, Rudolf Carnap, Charles Morris, eds., International Encyclopedia of Unified Science, Foundations of the Unity of Science, Volumes I-II of the Encyclopedia (Chicago: University of Chicago Press, 1944)

19 Otto Neurath, Rudolf Carnap, Charles Morris, eds., International Encyclopedia, 33.

20 Otto Neurath, 'Visual Education', 25.

21 Whenever I have capitalized the word 'Museum' it means that I am referring to the 'Museum of Society and Economy'.

22 Otto Neurath, 'Gesellschafts- und Wirtschaft im Lehrbild', Österreichische Gemeindezeitung, May 1, 1927, 44. 'Man muss nun darangehen, festzustellen, welche Lösungsweisen uns zur Verfügung stehen, es muss der Bereich der Darstellungsarten abgegrenzt werden. Leuchttafeln, Magnetkarten, Zeichenfilme, die alle bedürfen methodischer Pflege. Man muss allmählich feststellen, was man so darstellen kann, was nicht; welche Vorteile das ruhende statistische Bild vor all dem hat. Die Wirkung von statistischen Bildern, die abwechselnd aufleuchten, ist noch allzuwenig untersucht.'

23 Nader Vossoughian has described this notion in detail. Nader Vossoughian, Otto Neurath: The Language of the Global Polis, (Rotterdam: NAi Publishers, 2008), 79.

24 Otto Neurath, 'Bildhafte Pädagogik im Gesellschafts- und Wirtschaftsmuseum in Wien', Museumskunde, Neue Folge III (1931): 125-9. Neurath used the term Bildstatistik all throughout the 1920s and well into the 1930s. Although pedagogy had always been an element of Neurath's aspirations, it became the most important goal in the early 1930s when Picture Education replaced Picture Statistics for the first time in an article's headline in 'Bildhafte Pädagogik'. For the change in artice headlines see Robin Kinross, index to Band 3 Gesammelte bildpädagogische Schriften, by Otto Neurath, edited by Rudolf Haller and Robin Kinross (Vienna: HölderPichler-Tempsky, 1991) v-vi.

25 Otto Neurath, 'Bildhafte Pädagogik', 128. 'Das Gesellschafts- und Wirtschaftsmuseum beschränkt sich nicht auf Bildstatistik, es hat in seinen Werkstätten mit seinen Mitarbeitern noch eine Reihe musealer Hilfsmittel geschaffen, wie neuartige Karten in ungewöhnlichen, pädagogisch wirksamen Ausschnitten (Projektionen), technische Bildtafeln, insbesondere zur Rationalisierung großzügige Holzmodelle für seine Abteilung Wohnung und Städtebau, auf durchsichtigem Material Grundrisse übereinanderliegender Stockwerke, Magnettafeln zur Eintragung wechselnder Mengen; auch die Photographie wird zur Charakterisierung viel herangezogen.'

26 See Note to Illustration 2.24 and 2.25 in N. Vossoughian, Global Polis, 77.

27 Images are at the Otto and Marie Neurath Isotype Collection, University of Reading, 
Department of Typography.

28 Otto Neurath, Bildstatistik nach Wiener Methode in der Schule, (Vienna and Leipzig: Deutscher Verlag für Jugend und Volk, 1933), 39. 'Bilder der 10-14jährigen zeigen deutlich, wie die Aufgabe immer naturalistischer gelöst wird, wenn man nicht ausdrücklich die symbolische Darstellung verlangt.'

29 Otto Neurath, Bildstatistik in der Schule, 39-40. 'In einer Mädchenklasse z. B. sieht man Reihen von Mädchen, deren Kleidchen allerlei Details aufweisen. Zöpfe und anderes belebt die Situation. Die Mädchen, welche daheim bleiben, blicken etwa zum Fenster hinaus, dessen Gardinen liebevoll ausgemalt werden. Die Führungsbilder geben Anlass zu malerischer Betätigung. Allzuleicht verlieren sie den Charakter statistikfreier Symbolik.'

30 Otto Neurath, Bildstatistik in der Schule, 36. 'Während auf den unteren Stufen die Kinder, wie dies den Erfahrungen der Kinderpsychologie entspricht, sehr geeignet sind, Symbole zu erfinden und vereinfacht zu entwerfen, drängt sich auf höherer Stufe, insbesondere knapp vor der Pubertät, der Naturalismus vor, welcher die mannigfaltige, reiche Darstellung bevorzugt.'

31 Otto Neurath, Bildstatistik in der Schule, 39-40. 'Mit 6- und 7jährigen wird Bildstatistik anfangs am besten in der Weise betrieben, dass man Beispiele wählt, in denen ein Zeichen einen Gegenstand darstellt ... Es wird z. B. die Frage aufgeworfen: Wie viele Kinder waren am letzten Sonntag daheim, wie viele im Freien. [...] Die Erfindung von Zeichen ist auf dieser Stufe sehr aufschlussreich; [...] In einem anderen Fall hat ein Kind den "Sonntag im Freien" mit einem Baumsymbol, verbunden mit einem Pilzsymbol gekennzeichnet, unter Weglassung der Kinder, welche ins Freie wandern. Gefragt, weshalb es den Baum und den Pilz gewählt habe, antwortete es durchaus im Sinne bester Bildpädagogik: Der Baum alleine könnte einen Park in Wien bedeuten, durch den Pilz wird klar, dass es ein Wald sein soll.'

32 Otto Neurath, 'Visual education', 28. 'This visual method has special uses in teaching public health lessons, child care, safety, and so on, adults and to children, and in teaching retarded or handicapped children. The International Foundation for Visual Education is working along these lines in many countries.'

33 Kenneth Framton, 'Introduction', in Eric Mumford, The CIAM discourse on Urbanism, 1928-1960 (Cambridge and Massachusetts: MIT Press, 2000), xi.

34 For a detailed description of how the three CIAM model maps came into being see Kees Somer, The Functional City: The CIAM and Cornelis van Eesteren, 1928-1960 (Rotterdam: NAi Publishers, 2007), and Eric Mumford, CIAM.

35 Eric Mumford, CIAM, 62-63. 
36 Sigfried Giedion, 'Letter to Cornelis Van Eesteren, 21. 12. 1931', CIAM Archiv, 42-K-1931, Eidgenössische Technische Hochschule, Zürich, Switzerland. 'Vielleicht ist die erste Karte mit den Verkehrszeichen, die sich oft ähnlich sehen, nicht ganz leicht lesbar. Die zweite Karte jedoch ist beim ersten Anblick klar. Vielleicht sollten wir in Zukunft mit Spezialisten von Zahlenzeichen und Statistiken zusammenarbeiten. Wir wollen den Direktor des Wiener Gesellschaftsmuseum, Dr. Neurath, nach Zürich kommen lassen, da er meines Wissens über die grösste Erfahrung auf diesem Gebiete verfügt (erinnerst du dich an die Wandtafeln der österreichischen Abteilung der Berliner Bauausstellung?)'

37 Cornelis Van Eesteren, 'Methoden des Funktionellen Städtebaus', Technika Chronika, (1933): 1150. 'Über die Methoden städtebauliche Erscheinungen zu fassen, über die Erscheinung an sich und über Wege welche zum städtebaulichen Entwurf der Stadt der Zukunft führen, werde ich jetzt sprechen.'

38 Cornelis Van Eesteren, 'Funktioneller Städtebau', 1152. 'Im Generalplan hat man nun die Lage der grossen Einheiten anzudenken welche eine gute Situation im Bezug auf den ganzen Stadtkörper verlangen. Es sind dies Objekte, die in jeder Stadt vereinzelt vorkommen wie: Krankenhäuser, Irrenhäuser, Friedhöfe, Krematorien u.s.w.'

39 Cornelis Van Eesteren, 'Funktioneller Städtebau', 1152. 'Ausführliche demographische Studien wurden gemacht. Über Technische Einzelfragen, wie Eisenbahn, Uferverbindung, kam man zur Lösung und wurden ausführliche Berichte aufgestellt. Für die zu erwartende Bevölkerungszahl wurde eine Prognose aufgestellt und ein minimum und ein maximum festgestellt, für welche beiden Annahmen der Plan Wohnmöglichkeit bieten soll.'

40 Neurath's speech was printed in Technika Chronika which is available at the gta archive at the ETH, Zurich.

41 Otto Neurath, 'L’Urbanisme', 1153. 'Si l'on veut montrer la densité d'habitation dans les grandes villes mondiales d'apres notre méthode, celles-ci seront caracterisées par des médaillons, p. e. Paris par la tour Eiffel et Notre Dame, Londres par le pont sur la Tamise, etc. La densité d'habitation sera représentée par des figurines noires ou colorées. A première vue on constatera alors que dans les villes anglosaxonnes p.e. il y a par $100 \mathrm{~m}^{2}$, moins d'habitants que dans les villes d'Europe Centrale. Je n'entrerai pas dans des considérations pour savoir si le fait de l'habitation sur un seul ou sur deux étages détermine cette circonstance.'

42 Otto Neurath, 'L'Urbanisme', 1153-4. 'Il n’est pas toujours nécessaire de presenter ces graphiques sur des cartes géographiques; il suffit souvent d'employer des schémas géographiques ... Le schéme facilite l’observation. Je pense que nous 
pourrions mieux représenter une quantité de faits étudiés à ce Congrès par des schémas semblables, plutôt que par des plans et des cartes géographiques.'

43 Marie Reidemeister, 'Protocoll of the Publication comissions' meeting 12.8.33., Attachment Otto Neurath Letter to Sigfried Giedion, 19.8.1933', 1-2, CIAM Archiv, 42-K-1933, Eidgenössische Technische Hochschule, Zürich, Switzerland. 'aussprache ueber die veraenderung der bisherigen karten. M sehr dafür, weil eindrucksam und werdeprozess steigend. N sehr dagegen, weil vollkommenstes gezeigt werden soll einfache relationen der resolution an vereinfachten ausschnitten besser demonstrierbar. Zusammenarbeit zuerich, amsterdam, wien mit M., G., vE vermitteln, man einigt sich darauf, dass entwicklung der arbeit gezeigt wird mit beispielen aus karten, und zwar faelle groesster mannigfaltigkeit und faelle, die zu besonderer kritik anlass geben, um eventuell die notwendigkeit der mundaneumsarbeit zu entwickeln. M und vE betonen, dass das chaotische der stadt gezeigt werden soll.'

44 M. Reidemeister, 'Protocoll', 2. 'Die grosse publikation nach gruendlicher durcharbeitung mit vollkommener optischer darstellung.'

45 Cornelis Van Eesteren 'Letter to Lazlo Moholy-Nagy, 4.9. 1933', Vienna Circle Archive, 232, Noord-Hollands Archief, Haarlem, The Netherlands. 'Ich bin wirklich sehr froh darueber dass du den congress mitgemacht hast, nicht nur weil du einen schoenen congres-film gemacht hast und den schoenen fotos die wir noch zu sehen bekommen werden, aber vor allem weil du an der congres-arbeit so activ teil genommen hast. Von neuem hat es sich bewiesen, dass an unserem congres auch uns nahestehende nicht-architekten teilnehmen muessen. Besonders ist mir in erinnerung geblieben wie activ du an der besprechung mit Neurath teilgenommen hast - worin du immer das menschliche und psychologisch richtig wirkende in der diskussion nach vornen gebracht hast, sonst waeren wir sicher zu viel dem etwas begrenzten system Neurath's zum opfer gefallen. Du wirst bemerkt haben, dass ich waehrend den ganzen verhandlungen versuchte deine und Neurath's ideen fruchtbar aufeinander einwirken zu lassen, da ich davon fuer die publikation dieser congres-arbeit viel erwarte. Ich hoffe auf deine weitere schoepferische mitarbeit an der congressarbeit. Es wird noch viel noetig sein um mittel und wege zu finden um die wuensche zu verwirklichen.'

46 Otto Neurath, 'Letter to C.I.R.P.A.G., 24. 11.1933', CIAM Archiv, 42-K-1933, Eidgenössische Technische Hochschule, Zürich, Switzerland.

47 Otto Neurath, 'Letter to Cornelis van Eesteren 5. 12. 1933', Vienna Circle Archive, 232, Noord-Hollands Archief, Haarlem, The Netherlands. 'Bitte sagen Sie mir wie das alles Ihrer Meinung nach zu verstehen ist. Wenn prominente Mitglieder Ihres CIRPAC auf die Zusammenarbeit mit uns keinen Wert legen, würde ich es 
vorziehen, mit meinem Institut auszuscheiden, nicht ohne Ihnen und Ihrer liebeswürdigen Art des Verkehrs mit uns eine persönliche freundliche Erinnerung zu bewahren.

48 Cornelis Van Eesteren, 'Letter to Otto Neurath, 2. 5. 1934', Vienna Circle Archive, 232, Noord-Hollands Archief, Haarlem, The Netherlands.

49 Cornelis Van Eesteren, 'Letter to Sigfried Giedion 10.5.1934', Vienna Circle Archive, inv.nr. 232, Noord-Hollands Archief, Haarlem, The Netherlands. 'Neurath. [...] Ausgangspunkt ist immer noch, dass aus der zusammenarbeit zwischen kongres - und neurath etwas wachsen muss, sei es dass ... neurath so vollständig ist, dass wir damit erreichen (wovon ich noch nicht ueberzeugt bin) was wir vorhaben - oder dass wir daraus etwas neues wächst. Neurath hat die absicht nach london zu gehen und ich würde es begrüssen, wenn in diesem sinne mit ihm umgesprungen würde. Ich halte es für wichtig zu versuchen, dass wir mit ihm zu etwas kommen, du weißt aus barcelona wie kritisch ich seinen damaligen vorschlägen gegenüber stand, aber perönlich mit ihm zu etwas zu kommen, halte ich für möglich.'

50 Otto Neurath, 'Letter to Vornelis Van Eesteren 21.11.1934', Vienna Circle Archive, 232, Noord-Hollands Archief, Haarlem, The Netherlands. 'Wir haben die Zeichensache nun wieder um einiges gefördert. Die Schwierigkeit beruht darauf für eine bestimmte Art der Darstellung die Zeichen festzulegen, als damit Zeichen zu bekommen, die auch für andere Plandarstellungen verwendbar sind. Man soll womöglich Bevölkerungsdichte, Wohnungsanzahl, Stockwerkshöhe usw. kombinieren können und sowohl für jede Kombination zu Zweien, als auch zu mehr ein brauchbares Bild bekommen, das optisch orientiert.'

51 Kees Somer, Cornelis van Eesteren, 179.

52 Otto Neurath, 'Letter to Cornelis Van Eesteren 20.2. 1935', Vienna Circle Archive, 232, Noord-Hollands Archief, Haarlem, The Netherlands. 'Es war mir sehr leid, dass Sie nicht kamen. Sie sind immer so sänftigend. So vertrat ich mit freundlicher Unerbitterlichkeit das Prinzip, man müsse alles, was der Darstellung für eine etwas breitere Oeffentlichkeit dient, so gut pädagogisch bearbeiten, als es möglich ist. Die zögernde Zustimmung und geringe Bereitschaft BILDPÄDAGOGIK als eine Spezialität anzuerkennen ist mir vertraut.'

53 Otto Neurath, 'Letter to Cornelis Van Eesteren 20. 2. 1935', Vienna Circle Archive, 232, Noord-Hollands Archief, Haarlem, The Netherlands. 'Es lässt sich bei einiger Überlegung alles wirksam lösen aber das ist nicht nur eine graphische Aufgabe, so wenig es nur eine Architektenaufgabe ist, es bedarf der Dazwischenschaltung der TRANSFORMATION, das ist der bildpädagogischen Analyse und Richtung-gebung. Die Bemerkung, dass der Architekt nicht so 
viel Zeit für solche Sachen haben könne, beantworte ich mit dem Hinweis darauf: er solle auch die Zeit nicht auf so was verwenden, sondern das eben hiefür ausgebildeten Spezialisten über-lassen. Das ist aber das alte Lied, das ich Ihnen in verschiedenen Variationen schon vorgepfiffen habe und vorgeklimpert habe.'

54 Enrico Chapel, 'Otto Neurath and the CIAM - The International Pictorial Language as a Notational System for Town Planning', in Encyclopedia and Utopia, The Life and Work of Otto Neurath (1882-1945), edited by Elisabeth Nemeth and Friedrich Stadler (Dordrecht, Boston and London: Kluwer Academic Publishers, 1996), 'Town Planning', 175.

55 Enrico Chapel, 'Town Planning', 175.

56 Eric Mumford, CIAM, 20. 'But avoiding revolution, of course meant working closely with large interests with the capital to implement his overarching vision of social and architectural transformation. Such interests transcended national borders, and he was prepared to welcome capitalist internationalism in the service of social rationalization and reform along Taylorist lines.'

57 Enrico Chapel, 'Town Planning', 173.

58 Kees Somer, Cornelis van Eesteren, 179.

59 Otto Neurath, 'Architectural Problems', 58. 'Architects who are always closely connected with making floor plans and maps mostly intend to show social facts on maps; but in a great many cases we have to give preference to other methods of representation. We must avoid accumulating maps showing social data; it is more instructive to combine maps and pictographs. This leads us to a use of a symbol dictionary which contains symbols applicable to both maps and pictographs. This is the basis of visualization more widely applied.'

60 Otto Neurath, 'Architectural Problems', 59. 'The symbol, representing stations, factories, kindergartens, and other buildings are in black with a white design in the middle.'

61 Nader Vossoughian indicated that the 1937 map was Neurath's way of illustrating the functional city in his subtitle to 4.4., N. Vossoughian, Global Polis, I however, think Neurath solutions really wanted to contrast the Functional city.

62 Footnote to Otto Neurath, 'Architectural Problems', 57. 'See examples in Otto Neurath, Basic by Isotype, Kegan Paul, London, 1937, We can couple ISOTYPE standardization with various attempts at architectural representation, e. g. with the stimulating proposals of the CIRPAC made by Van Eesteren.'

63 Interview with Rem Koolhaas, April 13, 2010, see Appendix B, Sophie Hochhäusl, 'Otto Neurath - The Other Modern: Proposing a Socio-Political Map for Urbansim', (MA Thesis, Cornell University, 2010). 